\title{
Central bank independence and inflation revisited
}

\author{
Jeroen Klomp • Jakob de Haan
}

Received: 4 April 2010 / Accepted: 9 June 2010 / Published online: 1 July 2010

(C) The Author(s) 2010. This article is published with open access at Springerlink.com

\begin{abstract}
We re-examine the relationship between central bank independence (CBI), proxied by the central bank governor's turnover rate and an indicator based on central bank laws in place, and inflation using a random coefficient model with the Hildreth-Houck estimator for more than 100 countries in the period 1980 to 2005. We conclude that there exists no general significant negative relation between our indicators of central bank independence and inflation. Central bank independence has a significant effect only in a minority of the countries in our sample.
\end{abstract}

Keywords Central bank independence $\cdot$ Heterogeneous panel model $\cdot$ Inflation · Monetary institutions · Turnover of central bank governors

\section{JEL Classification E58}

\section{Introduction}

During the last two decades, many countries granted their monetary authorities greater independence. It is widely believed that central banks otherwise will give in to pressure from politicians who may be motivated by short-run electoral considerations (Kirchgässner 1983,

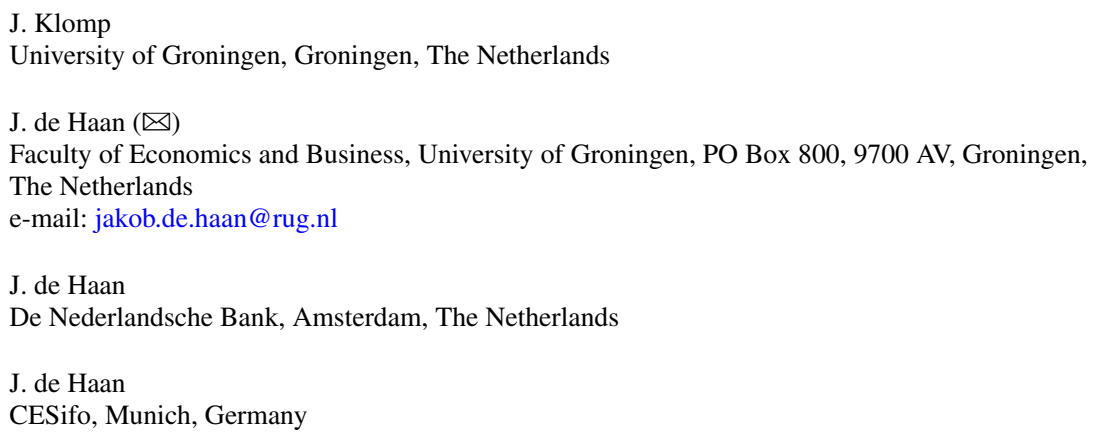


1991) or may value short-run economic expansions highly while discounting the longer-run inflationary consequences of expansionary policies (Walsh 2005). If the ability of politicians to distort monetary policy results in excessive inflation, countries with an independent central bank should experience lower rates of inflation. Indeed, an important line of empirical research focusing on the relationship between central bank independence (CBI) and inflation, suggests that average inflation is negatively related to measures of CBI (see Cukierman 2008 and Meade and Crowe 2007 for summaries).

To examine whether there is any relationship between CBI and inflation, one needs an indicator of the extent to which the monetary authorities are independent from politicians. Most empirical studies use either an indicator based on central bank laws in place, or the socalled turnover rate (TOR) of central bank governors. Legal measures of CBI may not reflect the true relationship between the central bank and the government. Especially in countries where the rule of law is less strongly embedded in the political culture, there can be wide gaps between the formal, legal institutional arrangements and their practical impact (Walsh 2005). This is particularly likely to be the case in many developing economies. Cukierman et al. (1992) argues that the actual average term in office of the central bank governor may therefore be a better proxy for CBI for these countries than measures based on central bank laws. The turnover rate (TOR) of central bank governors is based on the presumption that, at least above some threshold, higher turnover of central bank governors indicates a lower level of independence. ${ }^{1}$

In a recent meta-regression analysis of 57 empirical studies we conclude that legal CBI measures have a negative relationship with inflation in OECD countries, especially during the 1980s. Furthermore, studies based on the TOR suggest a positive relationship between this indicator of CBI and inflation in developing countries (see Klomp and De Haan 2010).

Many recent studies on the relationship between CBI and inflation are based on pooled data. However, Pesaran et al. (1999) argue that a pooled estimation procedure for (dynamic) panel models can produce inconsistent and misleading estimates of the long-run coefficients. The aim of this paper is to examine to what extent heterogeneity influences the relation between CBI and inflation using a panel model with some widely used controls included for the period 1980-2005. For this purpose, we use a random coefficient model with the Hildreth-Houck estimator as suggested by Bryk and Raudenbusch (1992) and the data of Dreher et al. (2008). This dataset comprises information on the TOR for a large number of countries over the period 1970 to 2005 . Estimating a model similar to that of Campillo and Miron (1997), we conclude that there exists no general significant relationship between the TOR and inflation. ${ }^{2}$ This CBI indicator is only significant in less then 20 percent of the countries. Similar results are found when a legal CBI indicator as provided by Arnone et al. (2007) is used.

The remainder of this paper is structured as follows. The next section gives a description of the methodology and data used. Section 3 shows our results on the relationship between $\mathrm{CBI}$ and inflation. The final section discusses our results and concludes.

\footnotetext{
${ }^{1}$ Still, this indicator is less than perfect, as it suffers from the limitation that central bank governors can hold office for quite some time simply by being subservient to political leaders. Furthermore, causality is difficult to evaluate; is inflation high because of political interference that leads to rapid turnover of central bank officials? Or are central bank officials tossed out because they can't keep inflation down (Walsh 2005)? Indeed, Dreher et al. (2008) find evidence that high past inflation increases the likelihood that a central bank governor will be replaced.

${ }^{2}$ Also some cross-sectional studies using quantile regressions (Koenker 2005) suggest that the impact of CBI on inflation is not identical across countries (see, for instance, Temple 1998 and Bouwman et al. 2005).
} 


\section{Data and methodology}

Most previous panel studies examining the relationship between central bank independence and inflation use some pooled estimator. However, there are some problems using a CBI indicator in panel estimations. First, legal CBI indicators are available only for some specific years, while it is not known what happens with the central bank law in place between those years. Most studies using panel estimators (e.g., Kilponen 1999; Franzese 1999; Dolmas et al. 2000; Jácome and Vázquez 2008) therefore estimate the relationship between inflation and CBI with a non-time-varying CBI indicator. Instead, we use a rolling average of the TOR over ten preceding years as our CBI indicator. So this indicator varies across time. As part of our sensitivity analysis we also use a legal CBI indicator as provided by Arnone et al. (2007). This indicator is available only for two points in time. Using information on the timing of changes in the central bank law as provided by Acemoglu et al. (2008), we are able to determine the value of the CBI indicator for the years in between these points.

Second, it is questionable whether a pooled estimator is the appropriate estimation technique in view of the possible heterogeneity in our large sample. To examine this issue in more detail, we use the (dynamic) random coefficient model with the Hildreth-Houck estimator suggested by Bryk and Raudenbusch (1992) to estimate the effect of CBI on inflation (cf. Han et al. 2002; Burney 1995, 1996; List and Gallet 1999; Garofalo and Yamarik 2002). ${ }^{3}$ In a random coefficient model (RCM), parameter heterogeneity is viewed as being due to stochastic variation. The RCM allows us to estimate the coefficient for each individual country. Using the parameter constancy test, we can examine whether the coefficients of our $\mathrm{CBI}$ indicator vary significantly across countries. If there is no heterogeneity, the estimated coefficients of the CBI indicator should be the same for all countries. In fact, this is what previous panel and cross-section studies on the relationship between CBI and inflation implicitly imposed. However, in the RCM both the random intercept and the slope parameters vary around common means. The random parameters can be considered outcomes of a common mean plus an error term, representing a deviation from the mean for each individual country. The random coefficient model starts from the assumption that the parameter differences across groups are caused by stochastic variation. In other words, the model can be specified as:

$$
\pi=\alpha_{i}+\beta_{i} X_{i, t}+\lambda_{i} \mathrm{CBI}_{i, t}+\varepsilon_{i, t}
$$

where $\alpha_{i}=\alpha_{0}+\kappa_{1}, \beta_{i}=\beta_{0}+v_{i}$ and $\lambda_{i}=\lambda_{0}+\omega_{i}$.

The parameters $\kappa, v$, and $\omega$ have multivariate normal distributions with mean zero. In general, the model assumes no autocorrelation within the panels to avoid complicating the covariance matrix. However, to ensure that we get robust standard errors we use clustered standard errors. We have an unbalanced panel of more than 100 countries for the period 1980 to 2005. The countries included in our analysis are listed in Table 5 in the Appendix. The variable $\pi$ is the modified inflation rate computed as $p /(1+p)$ where $p$ is the price change. With price increases, the transformed inflation rate takes a value from 0 to $1 .^{4} X_{i, t}$ is a vector of control variables. Our proxy for $\mathrm{CBI}$ is the turnover rate (TOR) of central bank governors.

\footnotetext{
${ }^{3}$ One problem with this estimator could be the low degrees of freedom for some individual countries. We therefore also estimated all regressions as reported in this paper including only countries for which we have at least 90 percent of the observations over 1980-2005 (i.e., about 85 percent of the sample). The results (available on request) do not change substantially.

${ }^{4}$ The transformation of the inflation rate reduces the heteroscedasticity of the error term. In case of price decreases it ranges between -1 to 0 .
} 


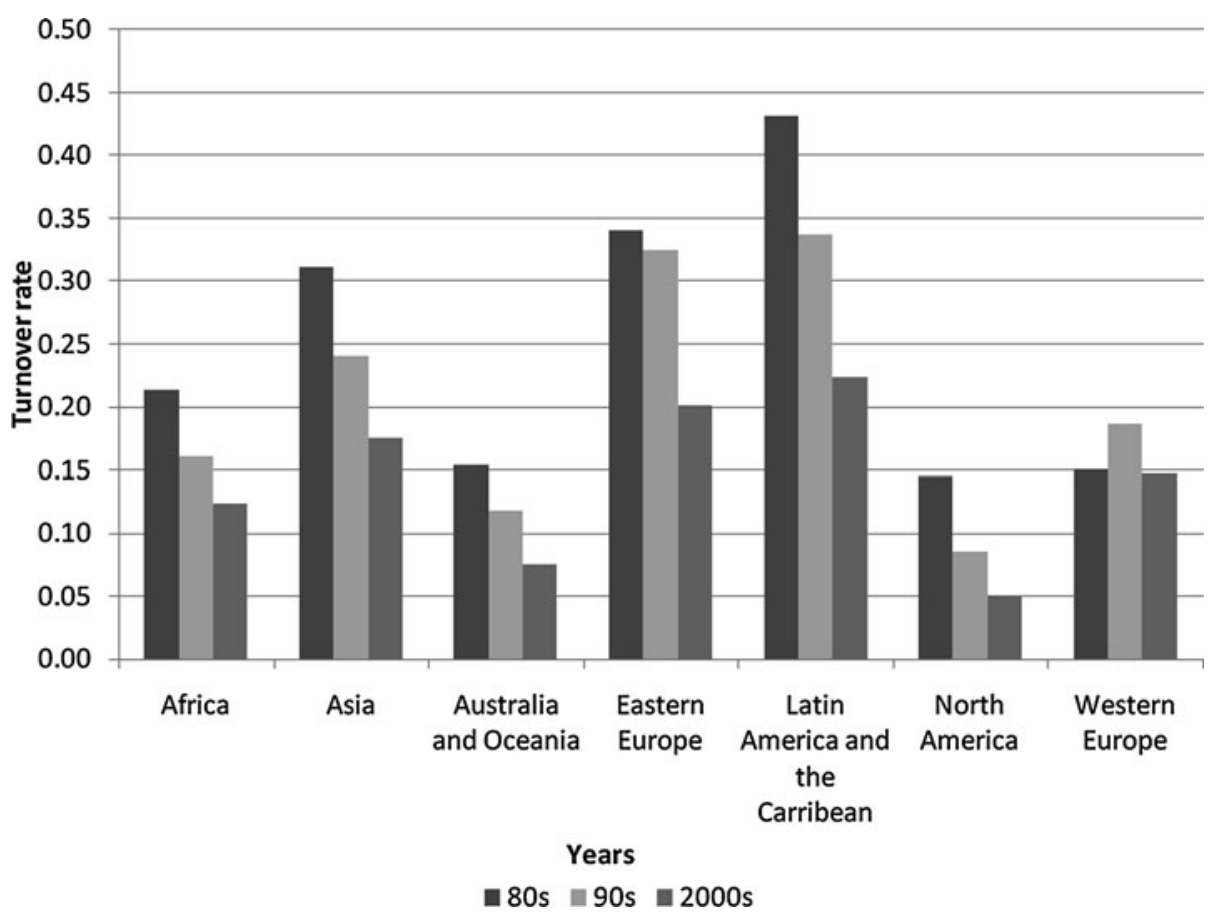

Fig. 1 Distribution of the turnover rate over time $(n=865)$

Various studies report that countries experiencing rapid turnover among their central bank governors also tend to experience high rates of inflation (see, for instance, Cukierman et al. 1992). ${ }^{5}$ We calculated the TOR using a rolling window of ten years. ${ }^{6}$ The final term $\varepsilon_{i}$ is an error term. Table 5 in the Appendix shows the number of central bank governors between 1970 and 2005 for every individual country. In Fig. 1 we show the distribution of the TOR over time and across country groups. The general pattern is that since the 1980s the TOR declines in almost all country groups. However, there are still large differences between country groups. Countries in Latin America and Eastern Europe have the highest TORs. On average, the TOR has a value of 0.2 , which means that once in every five years the central bank governor is replaced.

The control variables that we take into account come from the model of Campillo and Miron (1997). ${ }^{7}$ We include an indicator of openness, average GDP per capita, an exchange rate dummy, the average external debt-to-GDP ratio, and an indicator of political instability. Our indicator of openness is defined as sum of exports and imports in relation to GDP; data are taken from the World Bank's 2005 World Development Indicators CD-ROM. GDP per

\footnotetext{
${ }^{5}$ We follow most previous studies in this line of research (except for Dreher et al. 2008) by assuming that causality runs from TOR to inflation. The main purpose of our paper is to show that the standard assumption in the literature, namely that CBI affects inflation in all countries equally, may not be correct.

${ }^{6}$ We also experimented with rolling windows of five years, but it turned out that the main results do not change. Details are available on request.

${ }^{7}$ Our purpose is not to come up with a 'perfect' model. We include those control variables that have been widely used in the literature, thereby neglecting other variables that might play a role, like government ideology.
} 
capita and the external debt-to-GDP ratio are also from the World Bank. Our proxy for political instability is measured by the first principal component of the number of assassinations, strikes, guerrilla warfare, major crises, riots, and revolutions in a particular country and year taken from the Databanks International (2005) Cross-National Time-Series Data Archive. The exchange rate regime dummy is one if there is a fixed exchange rate regime according to the de-facto classification of exchange rate regimes in Levy-Yeyati and Sturzenegger (2005), and zero otherwise. The control variables are entered with a lag to control for the endogeneity problem. ${ }^{8}$

\section{Estimation results}

Column (1) of Table 1 first shows the estimates of the traditional pooled regression without controlling for country and time effects. The results indicate a strong positive relation between the TOR and inflation. This finding is in line with the results of most previous studies. In column (2) we drop the debt variable, which increases the sample size about six times. The results for the TOR variable remain the same. This is also the case when we control for country and time effects, although the effect of CBI on inflation is somewhat smaller (columns 3 and 4).

The second part of Table 1 shows the estimates of the random coefficient model. The significance of the parameter constancy test indicates that jointly the coefficients are not homogeneous across countries and that the random coefficient model is the appropriate one to use. This is confirmed if we only perform a heterogeneity test on the coefficients of our $\mathrm{CBI}$ indicator, which is significant at the $5 \%$ level. The results for the CBI indicator change substantially as it is generally insignificant. This means that we do not find a general relation between the independence of the central bank and the level of inflation. However, a closer look at the individual country level results shown in Fig. 2 suggests that in some countries there is a significant relationship between CBI and inflation. Still, the number of countries in which the coefficient of the TOR is significant is limited: less then $20 \%$ of our sample. Most of these countries are developing countries. As a sensitivity test, we have re-estimated our model differentiating between countries that had an inflation rate above $50 \%$ and those that had an inflation rate below this threshold. In both samples, the CBI coefficient is generally insignificant (results available on request).

As a further test, we have used a legal CBI measure as provided by Arnone et al. (2007) instead of the TOR. Arnone et al. (2007) provide indicators for about 163 central banks based on the methodology proposed by Grilli et al. (1991), which distinguishes between political autonomy (i.e., the ability of the central bank to select the objectives of monetary policy) and economic autonomy (i.e., the ability of the central bank to select its instruments). Unfortunately, this CBI indicator is available only for two points in time, namely 1989 and 2003. Using the information provided by Acemoglu et al. (2008) on the timing of central bank law reform, we assigned values to the legal CBI indicator for the years in between. To illustrate our approach: suppose that in country A the legal CBI indicator has a value of 0.5 in 1989 and 0.7 in 2003 according to the data of Arnone et al. 2007 and that according to the data of Acemoglu et al. (2008) the central bank law was changed in 2000. Our legal CBI measure for country A is then 0.5 until 2000 and 0.7 from 2000 onwards.

Table 2 replicates the regressions of Table 1 using the legal CBI indicator instead of the TOR. The results confirm our earlier findings. In the pooled model—shown in columns (1) to

\footnotetext{
${ }^{8}$ Table 4 in the Appendix gives a statistical summary of the data used. See also Dreher et al. (2008).
} 
Table 1 Estimation results I-TOR central bank independence measure

\begin{tabular}{|c|c|c|c|c|c|c|}
\hline & \multicolumn{4}{|c|}{ Pooled evidence } & \multicolumn{2}{|c|}{ Random coefficient model } \\
\hline & $(1)$ & $(2)$ & (3) & (4) & $(5)$ & (6) \\
\hline Trade openness & $\begin{array}{l}-0.0007 \\
{[-3.97]}\end{array}$ & $\begin{array}{l}-0.0004 \\
{[-5.53]}\end{array}$ & $\begin{array}{l}0.0005 \\
{[2.78]}\end{array}$ & $\begin{array}{l}0.0009 \\
{[5.14]}\end{array}$ & $\begin{array}{l}0.0007 \\
{[1.97]}\end{array}$ & $\begin{array}{l}0.0008 \\
{[1.72]}\end{array}$ \\
\hline Income per capita & $\begin{array}{l}-0.022 \\
{[-2.67]}\end{array}$ & $\begin{array}{l}-0.019 \\
{[-6.74]}\end{array}$ & $\begin{array}{l}-0.119 \\
{[-9.18]}\end{array}$ & $\begin{array}{l}-0.067 \\
{[-4.80]}\end{array}$ & $\begin{array}{l}-0.033 \\
{[-0.49]}\end{array}$ & $\begin{array}{l}-0.062 \\
{[-1.19]}\end{array}$ \\
\hline Political instability & $\begin{array}{l}0.015 \\
{[1.41]}\end{array}$ & $\begin{array}{l}0.021 \\
{[4.07]}\end{array}$ & $\begin{array}{l}0.020 \\
{[4.33]}\end{array}$ & $\begin{array}{l}0.019 \\
{[4.32]}\end{array}$ & $\begin{array}{l}0.040 \\
{[0.45]}\end{array}$ & $\begin{array}{l}0.032 \\
{[0.50]}\end{array}$ \\
\hline Fixed exchange rate & $\begin{array}{l}-0.023 \\
{[-1.46]}\end{array}$ & $\begin{array}{l}-0.057 \\
{[-9.47]}\end{array}$ & $\begin{array}{l}-0.055 \\
{[-9.13]}\end{array}$ & $\begin{array}{l}-0.053 \\
{[-9.08]}\end{array}$ & $\begin{array}{l}-0.018 \\
{[-2.13]}\end{array}$ & $\begin{array}{l}-0.014 \\
{[-1.82]}\end{array}$ \\
\hline Government debt & $\begin{array}{l}0.010 \\
{[5.36]}\end{array}$ & & & & & \\
\hline Central bank independence & $\begin{array}{l}0.215 \\
{[4.49]}\end{array}$ & $\begin{array}{l}0.279 \\
{[15.47]}\end{array}$ & $\begin{array}{l}0.174 \\
{[8.43]}\end{array}$ & $\begin{array}{l}0.099 \\
{[4.71]}\end{array}$ & $\begin{array}{l}0.185 \\
{[1.46]}\end{array}$ & $\begin{array}{l}0.054 \\
{[1.14]}\end{array}$ \\
\hline Number of countries & 118 & 118 & 118 & 118 & 118 & 103 \\
\hline Number of observations & 539 & 2523 & 2523 & 2523 & 2523 & 2398 \\
\hline Average time-series & 4.57 & 21.38 & 21.38 & 21.38 & 21.38 & 23.28 \\
\hline$R$-squared & 0.21 & 0.19 & 0.07 & 0.08 & & \\
\hline$F$-test $p$-value & 0.000 & 0.000 & 0.000 & 0.000 & & \\
\hline Parameter constancy $p$-value & & & & & 0.000 & 0.000 \\
\hline Wald test $p$-value & & & & & 0.027 & 0.058 \\
\hline Country effect & no & no & yes & yes & - & - \\
\hline Time effect & no & no & no & yes & no & yes \\
\hline
\end{tabular}

$t$-value between brackets

Fig. 2 CBI coefficient distribution-TOR measure

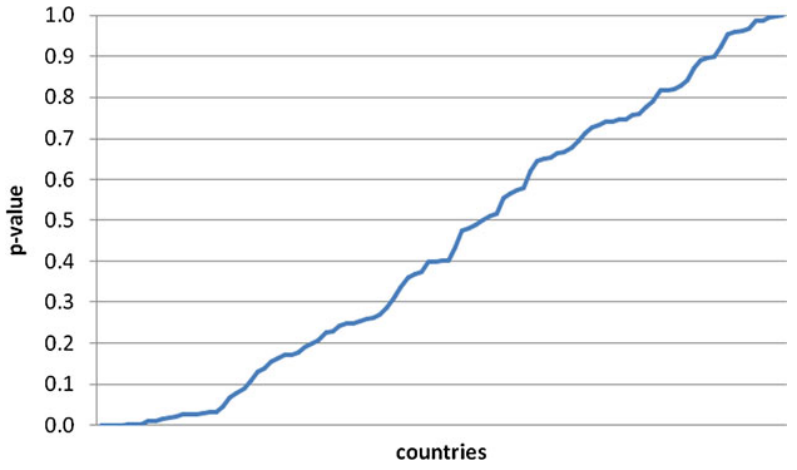

(4) - we find a significant effect of CBI on inflation. However, when we use a heterogeneous model in columns (5) and (6), which is appropriate as indicated by the parameter constancy test, we do not find a general significant relation between CBI and inflation. Again, the distribution across countries as shown in Fig. 3 suggests that in some countries the coefficient of the CBI indicator is significant. In this case, the set of countries with a significant CBI coefficient comprises industrial as well as developing countries. To sum up our results, we 
Table 2 Estimation results II-legal central bank independence measure

\begin{tabular}{|c|c|c|c|c|c|c|}
\hline & \multicolumn{4}{|c|}{ Pooled evidence } & \multicolumn{2}{|c|}{ Random coefficient model } \\
\hline & $(1)$ & $(2)$ & (3) & (4) & $(5)$ & (6) \\
\hline Trade openness & $\begin{array}{l}-0.0002 \\
{[-1.56]}\end{array}$ & $\begin{array}{l}-0.0002 \\
{[-1.69]}\end{array}$ & $\begin{array}{l}0.0007 \\
{[3.22]}\end{array}$ & $\begin{array}{l}0.0011 \\
{[5.35]}\end{array}$ & $\begin{array}{l}0.0002 \\
{[0.32]}\end{array}$ & $\begin{array}{l}0.0003 \\
{[0.35]}\end{array}$ \\
\hline Income per capita & $\begin{array}{l}-0.011 \\
{[-1.52]}\end{array}$ & $\begin{array}{l}-0.030 \\
{[-8.41]}\end{array}$ & $\begin{array}{l}-0.055 \\
{[-2.50]}\end{array}$ & $\begin{array}{l}0.055 \\
{[2.35]}\end{array}$ & $\begin{array}{l}-0.045 \\
{[-0.65]}\end{array}$ & $\begin{array}{l}-0.022 \\
{[-0.21]}\end{array}$ \\
\hline Political instability & $\begin{array}{l}0.020 \\
{[2.21]}\end{array}$ & $\begin{array}{l}0.026 \\
{[4.19]}\end{array}$ & $\begin{array}{l}0.024 \\
{[3.92]}\end{array}$ & $\begin{array}{l}0.027 \\
{[4.58]}\end{array}$ & $\begin{array}{l}0.042 \\
{[0.11]}\end{array}$ & $\begin{array}{l}-0.129 \\
{[-0.07]}\end{array}$ \\
\hline Fixed exchange rate & $\begin{array}{l}-0.055 \\
{[-4.25]}\end{array}$ & $\begin{array}{l}-0.059 \\
{[-7.55]}\end{array}$ & $\begin{array}{l}-0.062 \\
{[-7.63]}\end{array}$ & $\begin{array}{l}-0.062 \\
{[-7.86]}\end{array}$ & $\begin{array}{l}-0.018 \\
{[-2.12]}\end{array}$ & $\begin{array}{l}-0.017 \\
{[-1.92]}\end{array}$ \\
\hline Government debt & $\begin{array}{l}0.007 \\
{[4.38]}\end{array}$ & & & & & \\
\hline Central bank independence & $\begin{array}{l}-0.079 \\
{[-3.00]}\end{array}$ & $\begin{array}{l}-0.012 \\
{[-2.62]}\end{array}$ & $\begin{array}{l}-0.179 \\
{[-6.28]}\end{array}$ & $\begin{array}{l}-0.121 \\
{[-4.30]}\end{array}$ & $\begin{array}{l}-0.101 \\
{[-0.97]}\end{array}$ & $\begin{array}{l}-0.081 \\
{[-0.86]}\end{array}$ \\
\hline Number of countries & 128 & 128 & 128 & 128 & 128 & 121 \\
\hline Number of observations & 664 & 2005 & 2005 & 2005 & 2001 & 1955 \\
\hline Average time-series & 5.19 & 15.66 & 15.66 & 15.66 & 15.63 & 16.16 \\
\hline$R$-squared & 0.12 & 0.10 & 0.06 & 0.04 & & \\
\hline$F$-test $p$-value & 0.000 & 0.000 & 0.000 & 0.000 & & \\
\hline Parameter constancy $p$-value & & & & & 0.000 & 0.000 \\
\hline Wald test $p$-value & & & & & 0.040 & 0.010 \\
\hline Country effect & no & no & yes & yes & - & - \\
\hline Time effect & no & no & no & yes & no & yes \\
\hline
\end{tabular}

$t$-value between brackets

Fig. 3 CBI coefficient distribution-legal measure

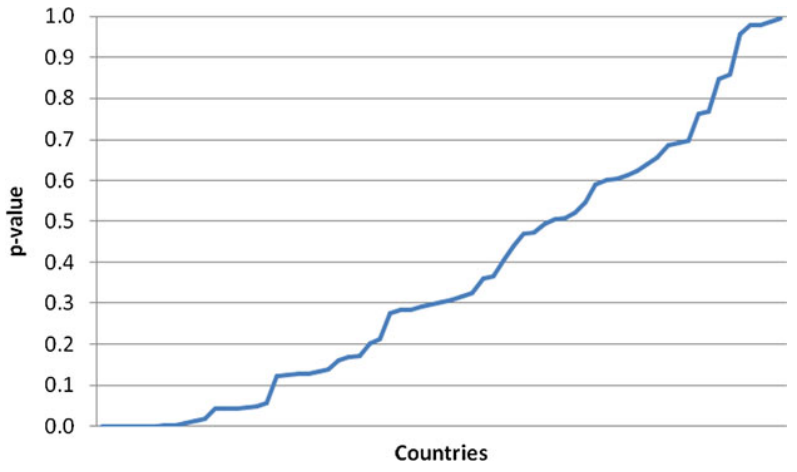

find no general significant relation between inflation and CBI, although for some countries this relation turns out to be significant.

As further robustness checks we have performed two more sensitivity analyses. First, we employ a bootstrap estimation. This method replicates the regressions 1,000 times by estimating them with various subsamples of countries. The bootstrap results for the CBI variables are in line with our previous findings. Columns (1) and (2) of Table 3 show the 
Table 3 Estimation results III-sensitivity analysis

\begin{tabular}{|c|c|c|c|c|}
\hline & \multicolumn{2}{|c|}{ Bootstrap } & \multirow{2}{*}{$\begin{array}{l}\text { Developing } \\
\text { TOR } \\
(3)\end{array}$} & \multirow{2}{*}{$\begin{array}{l}\text { Developed } \\
\text { Legal } \\
(4)\end{array}$} \\
\hline & (1) & (2) & & \\
\hline \multirow[t]{2}{*}{ Trade openness } & 0.0008 & 0.0003 & 0.001 & -0.004 \\
\hline & {$[1.42]$} & {$[0.10]$} & {$[1.85]$} & {$[-0.77]$} \\
\hline \multirow[t]{2}{*}{ Income per capita } & -0.062 & -0.022 & -0.032 & -0.067 \\
\hline & {$[-0.90]$} & {$[-0.03]$} & {$[-0.49]$} & {$[-1.01]$} \\
\hline \multirow[t]{2}{*}{ Political instability } & 0.032 & -0.129 & 0.038 & -0.016 \\
\hline & {$[0.14]$} & {$[-0.21]$} & {$[0.46]$} & {$[-0.19]$} \\
\hline \multirow[t]{2}{*}{ Fixed exchange rate } & -0.014 & -0.017 & -0.016 & -0.007 \\
\hline & {$[-2.03]$} & {$[-0.19]$} & {$[-1.53]$} & {$[-1.02]$} \\
\hline \multicolumn{5}{|l|}{ Government debt } \\
\hline \multirow[t]{2}{*}{ Central bank independence } & 0.054 & -0.081 & 0.067 & -0.014 \\
\hline & {$[0.85]$} & {$[-0.89]$} & {$[0.73]$} & {$[-0.04]$} \\
\hline Number of countries & 103 & 121 & 77 & 30 \\
\hline Number of observations & 2398 & 1955 & 1755 & 509 \\
\hline Average time-series & 23.28 & 16.16 & 22.79 & 16.97 \\
\hline Country effect & 0.000 & 0.000 & 0.000 & 0.000 \\
\hline Time effect & 0.020 & 0.053 & 0.13 & 0.09 \\
\hline
\end{tabular}

$t$-value between brackets

estimates of the bootstrap regression with, respectively, the TOR and the legal indicator. In both cases, the results are in line with our previous findings.

Finally, we test for differences between developing and industrial countries. As noted, previous studies suggested that the legal indicator works best for industrial countries, while the TOR works best for developing countries (see Klomp and De Haan 2010 for further details). So, we replicated the last regression of Table 1 with developing countries only, while we replicated the last regression of Table 2 with OECD countries only. The results are in line with the total sample results (see the last columns in Table 3).

\section{Conclusions}

It is widely believed that central banks that are not independent will give in to pressure from politicians who may be motivated by short-run electoral considerations or may value shortrun economic expansions highly while discounting the longer-run inflationary consequences of expansionary policies. Consequently, inflation will be sub-optimally high. Indeed, most empirical research focusing on the relationship between central bank independence (CBI) and inflation suggests that average inflation is negatively related to measures of CBI. The aim of this paper is to estimate the extent to which heterogeneity influences the relation between CBI and inflation. We use a random coefficient model with the Hildreth-Houck estimator as suggested by Bryk and Raudenbusch (1992) for some 120 countries in the period 1980 to 2005 . We conclude that a heterogeneous model is the appropriate model for estimating the relationship between CBI and inflation. Our evidence suggests that there 
exists no general significant negative relation between $\mathrm{CBI}$ and inflation. CBI has only a significant effect in less than $20 \%$ of the countries.

What are the implications of our analysis? We certainly would not conclude that CBI is totally irrelevant. Even though our results suggest that CBI may be less important than generally thought, they also suggest that in various countries CBI is related to inflation. In our view, the major research question for future research is therefore to determine under which circumstances CBI matters. In other words, what are the conditioning variables for $\mathrm{CBI}$ to have an impact on inflation?

Acknowledgements We like to thank two anonymous referees and Lars Feld for their helpful comments on a previous version of the paper. The views expressed do not necessarily coincide with those of De Nederlandsche Bank.

Open Access This article is distributed under the terms of the Creative Commons Attribution Noncommercial License which permits any noncommercial use, distribution, and reproduction in any medium, provided the original author(s) and source are credited.

\section{Appendix}

Table 4 Data summary

\begin{tabular}{llllll}
\hline & Observations & Average & S.D. & $\min$ & $\max$ \\
\hline Inflation & 4436 & 0.115 & 0.151 & -0.277 & 0.996 \\
Trade openness & 4965 & 76.014 & 44.227 & 1.531 & 330.596 \\
Income per capita & 4314 & 8.415 & 1.101 & 6.116 & 10.983 \\
Political instability & 5296 & 0.000 & 0.665 & -0.524 & 17.843 \\
Fixed exchange rate & 7488 & 0.362 & 0.481 & 0.000 & 1.000 \\
Government debt & 907 & 2.227 & 8.699 & -21.249 & 203.719 \\
Central bank independence-TOR & 3442 & 0.235 & 0.187 & 0.000 & 1.000 \\
Central bank independence-Legal & 3318 & 0.488 & 0.215 & 0.090 & 1.000 \\
\hline
\end{tabular}

Table 5 Countries included in the analysis

\begin{tabular}{lllllll}
\hline Country & Year & Average TOR & Table 2 & & Table 3 \\
\cline { 5 - 6 } & & & Pooling & RCM & Pooling & RCM \\
\hline Algeria & 1980 & 0.23 & $\bullet$ & & $\bullet$ & $\bullet$ \\
Angola & 1985 & & & $\bullet$ & $\bullet$ & $\bullet$ \\
Argentina & 1980 & 0.77 & $\bullet$ & $\bullet$ & $\bullet$ & $\bullet$ \\
Australia & 1980 & 0.13 & $\bullet$ & & $\bullet$ \\
Austria & 1980 & 0.20 & $\bullet$ & $\bullet$ & $\bullet$ \\
Bahamas, The & 1980 & 0.12 & $\bullet$ & $\bullet$ & $\bullet$ \\
Bahrain & 1980 & 0.07 & $\bullet$ & $\bullet$ & $\bullet$ \\
Bangladesh & 1980 & 0.21 & $\bullet$ & $\bullet$ & $\bullet$ \\
Barbados & 1980 & 0.17 & $\bullet$ & $\bullet$ & $\bullet$ \\
Belgium & 1980 & 0.12 & $\bullet$ & $\bullet$ & $\bullet$ \\
Belize & 1980 & 0.26 & $\bullet$ & $\bullet$ & $\bullet$ \\
\hline
\end{tabular}


Table 5 (Continued)

\begin{tabular}{|c|c|c|c|c|c|c|}
\hline \multirow[t]{2}{*}{ Country } & \multirow[t]{2}{*}{ Year } & \multirow[t]{2}{*}{ Average TOR } & \multicolumn{2}{|l|}{ Table 2} & \multicolumn{2}{|l|}{ Table 3} \\
\hline & & & Pooling & $\mathrm{RCM}$ & Pooling & $\overline{\mathrm{RCM}}$ \\
\hline Bolivia & 1980 & 0.66 & $\bullet$ & $\bullet$ & $\bullet$ & $\bullet$ \\
\hline Botswana & 1980 & 0.24 & $\bullet$ & $\bullet$ & $\bullet$ & $\bullet$ \\
\hline Brazil & 1980 & 0.81 & $\bullet$ & $\bullet$ & $\bullet$ & $\bullet$ \\
\hline Bulgaria & 1980 & 0.24 & - & $\bullet$ & $\bullet$ & $\bullet$ \\
\hline Burundi & 1980 & 0.16 & $\bullet$ & $\bullet$ & $\bullet$ & $\bullet$ \\
\hline Cambodia & 1985 & & & & $\bullet$ & $\bullet$ \\
\hline Canada & 1980 & 0.14 & $\bullet$ & $\bullet$ & $\bullet$ & $\bullet$ \\
\hline Cape Verde & 1980 & 0.09 & $\bullet$ & $\bullet$ & $\bullet$ & $\bullet$ \\
\hline Central African Republic & 1980 & 0.06 & - & $\bullet$ & & \\
\hline Chad & 1980 & 0.06 & $\bullet$ & $\bullet$ & & \\
\hline Chile & 1980 & 0.44 & $\bullet$ & $\bullet$ & $\bullet$ & $\bullet$ \\
\hline China & 1980 & 0.26 & $\bullet$ & $\bullet$ & $\bullet$ & $\bullet$ \\
\hline Colombia & 1980 & 0.15 & - & $\bullet$ & - & $\bullet$ \\
\hline Congo, Dem. Rep. & 1980 & 0.06 & $\bullet$ & & & \\
\hline Costa Rica & 1980 & 0.36 & $\bullet$ & $\bullet$ & $\bullet$ & $\bullet$ \\
\hline Cyprus & 1980 & 0.05 & $\bullet$ & $\bullet$ & $\bullet$ & $\bullet$ \\
\hline Czech Republic & 1980 & 0.25 & $\bullet$ & $\bullet$ & $\bullet$ & $\bullet$ \\
\hline Denmark & 1980 & 0.20 & $\bullet$ & $\bullet$ & $\bullet$ & $\bullet$ \\
\hline Djibouti & 1980 & 0.12 & $\bullet$ & $\bullet$ & & \\
\hline Dominican Republic & 1980 & 0.45 & $\bullet$ & $\bullet$ & $\bullet$ & $\bullet$ \\
\hline Ecuador & 1980 & 0.85 & $\bullet$ & $\bullet$ & $\bullet$ & $\bullet$ \\
\hline Egypt, Arab Rep. & 1980 & 0.22 & $\bullet$ & $\bullet$ & $\bullet$ & $\bullet$ \\
\hline El Salvador & 1980 & 0.33 & - & $\bullet$ & $\bullet$ & $\bullet$ \\
\hline Equatorial Guinea & 1980 & 0.06 & $\bullet$ & $\bullet$ & $\bullet$ & $\bullet$ \\
\hline Estonia & 1990 & 0.38 & $\bullet$ & & $\bullet$ & \\
\hline Ethiopia & 1980 & 0.20 & $\bullet$ & $\bullet$ & $\bullet$ & $\bullet$ \\
\hline Fiji & 1980 & 0.20 & $\bullet$ & $\bullet$ & $\bullet$ & $\bullet$ \\
\hline Finland & 1980 & 0.17 & $\bullet$ & $\bullet$ & $\bullet$ & $\bullet$ \\
\hline France & 1980 & 0.17 & $\bullet$ & $\bullet$ & $\bullet$ & $\bullet$ \\
\hline Gabon & 1980 & 0.06 & $\bullet$ & $\bullet$ & & \\
\hline Gambia, The & 1980 & 0.19 & $\bullet$ & $\bullet$ & & \\
\hline Georgia & 1980 & 0.29 & $\bullet$ & $\bullet$ & $\bullet$ & $\bullet$ \\
\hline Germany & 1980 & 0.22 & $\bullet$ & $\bullet$ & $\bullet$ & $\bullet$ \\
\hline Ghana & 1980 & 0.16 & • & $\bullet$ & $\bullet$ & $\bullet$ \\
\hline Greece & 1980 & 0.23 & $\bullet$ & $\bullet$ & $\bullet$ & $\bullet$ \\
\hline Guatemala & 1980 & 0.59 & $\bullet$ & $\bullet$ & $\bullet$ & $\bullet$ \\
\hline Guinea & 1980 & 0.20 & $\bullet$ & $\bullet$ & $\bullet$ & $\bullet$ \\
\hline Guyana & 1980 & 0.09 & $\bullet$ & $\bullet$ & $\bullet$ & $\bullet$ \\
\hline Haiti & 1980 & 0.65 & $\bullet$ & - & - & $\bullet$ \\
\hline Honduras & 1980 & 0.20 & $\bullet$ & $\bullet$ & $\bullet$ & $\bullet$ \\
\hline Hungary & 1980 & 0.21 & $\bullet$ & $\bullet$ & $\bullet$ & $\bullet$ \\
\hline Iceland & 1980 & 0.10 & $\bullet$ & • & $\bullet$ & $\bullet$ \\
\hline India & 1980 & 0.30 & • & $\bullet$ & $\bullet$ & $\bullet$ \\
\hline
\end{tabular}


Table 5 (Continued)

\begin{tabular}{|c|c|c|c|c|c|c|}
\hline \multirow[t]{2}{*}{ Country } & \multirow[t]{2}{*}{ Year } & \multirow[t]{2}{*}{ Average TOR } & \multicolumn{2}{|l|}{ Table 2} & \multicolumn{2}{|l|}{ Table 3} \\
\hline & & & Pooling & RCM & Pooling & $\mathrm{RCM}$ \\
\hline Indonesia & 1980 & 0.19 & - & - & - & - \\
\hline Iran, Islamic Rep. & 1980 & 0.24 & $\bullet$ & $\bullet$ & $\bullet$ & $\bullet$ \\
\hline Ireland & 1980 & 0.15 & $\bullet$ & $\bullet$ & $\bullet$ & $\bullet$ \\
\hline Israel & 1980 & 0.21 & - & - & - & - \\
\hline Italy & 1980 & 0.07 & $\bullet$ & $\bullet$ & $\bullet$ & $\bullet$ \\
\hline Jamaica & 1980 & 0.37 & - & - & - & - \\
\hline Japan & 1980 & 0.21 & $\bullet$ & $\bullet$ & $\bullet$ & $\bullet$ \\
\hline Jordan & 1980 & 0.17 & $\bullet$ & $\bullet$ & $\bullet$ & $\bullet$ \\
\hline Kazakhstan & 1980 & 0.27 & $\bullet$ & - & $\bullet$ & $\bullet$ \\
\hline Kenya & 1980 & 0.15 & $\bullet$ & $\bullet$ & $\bullet$ & $\bullet$ \\
\hline Korea, Rep. & 1985 & & & & - & - \\
\hline Kuwait & 1980 & 0.09 & $\bullet$ & $\bullet$ & $\bullet$ & $\bullet$ \\
\hline Kyrgyz Republic & 1985 & & & & $\bullet$ & $\bullet$ \\
\hline Lao PDR & 1985 & & & $\bullet$ & $\bullet$ & - \\
\hline Latvia & 1986 & 0.29 & - & - & - & - \\
\hline Lebanon & 1980 & 0.20 & - & & $\bullet$ & $\bullet$ \\
\hline Lesotho & 1980 & 0.21 & - & - & - & - \\
\hline Lithuania & 1985 & 0.61 & $\bullet$ & $\bullet$ & $\bullet$ & $\bullet$ \\
\hline Luxembourg & 1985 & & & & - & - \\
\hline Macedonia, FYR & 1985 & & & - & $\bullet$ & $\bullet$ \\
\hline Madagascar & 1980 & 0.20 & - & - & - & - \\
\hline Malawi & 1980 & 0.27 & $\bullet$ & $\bullet$ & $\bullet$ & $\bullet$ \\
\hline Malaysia & 1980 & 0.19 & $\bullet$ & $\bullet$ & $\bullet$ & $\bullet$ \\
\hline Malta & 1980 & 0.20 & - & - & - & - \\
\hline Mauritius & 1980 & 0.12 & $\bullet$ & $\bullet$ & $\bullet$ & $\bullet$ \\
\hline Mexico & 1980 & 0.24 & $\bullet$ & $\bullet$ & $\bullet$ & $\bullet$ \\
\hline Moldova & 1990 & & & & $\bullet$ & \\
\hline Mongolia & 1980 & 0.20 & - & & - & - \\
\hline Morocco & 1980 & 0.11 & $\bullet$ & & $\bullet$ & $\bullet$ \\
\hline Mozambique & 1980 & 0.14 & - & - & - & - \\
\hline Namibia & 1985 & 0.45 & $\bullet$ & $\bullet$ & $\bullet$ & $\bullet$ \\
\hline Nepal & 1980 & 0.20 & $\bullet$ & $\bullet$ & $\bullet$ & $\bullet$ \\
\hline Netherlands & 1980 & 0.08 & - & $\bullet$ & $\bullet$ & $\bullet$ \\
\hline New Zealand & 1980 & 0.15 & $\bullet$ & $\bullet$ & $\bullet$ & $\bullet$ \\
\hline Nicaragua & 1980 & 0.47 & - & - & - & - \\
\hline Nigeria & 1980 & 0.10 & $\bullet$ & $\bullet$ & $\bullet$ & $\bullet$ \\
\hline Norway & 1980 & 0.18 & $\bullet$ & $\bullet$ & $\bullet$ & $\bullet$ \\
\hline Oman & 1985 & & & & $\bullet$ & $\bullet$ \\
\hline Pakistan & 1980 & 0.29 & $\bullet$ & $\bullet$ & $\bullet$ & $\bullet$ \\
\hline Panama & 1980 & 0.38 & $\bullet$ & & $\bullet$ & $\bullet$ \\
\hline Papua New Guinea & 1990 & & & & - & \\
\hline Paraguay & 1980 & 0.30 & $\bullet$ & $\bullet$ & $\bullet$ & $\bullet$ \\
\hline Peru & 1980 & 0.44 & - & - & - & - \\
\hline
\end{tabular}


Table 5 (Continued)

\begin{tabular}{|c|c|c|c|c|c|c|}
\hline \multirow[t]{2}{*}{ Country } & \multirow[t]{2}{*}{ Year } & \multirow[t]{2}{*}{ Average TOR } & \multicolumn{2}{|l|}{ Table 2} & \multicolumn{2}{|l|}{ Table 3} \\
\hline & & & Pooling & $\mathrm{RCM}$ & Pooling & RCM \\
\hline Philippines & 1980 & 0.20 & $\bullet$ & - & $\bullet$ & $\bullet$ \\
\hline Poland & 1980 & 0.42 & $\bullet$ & & $\bullet$ & $\bullet$ \\
\hline Portugal & 1980 & 0.28 & $\bullet$ & & $\bullet$ & $\bullet$ \\
\hline Romania & 1980 & 0.20 & $\bullet$ & $\bullet$ & $\bullet$ & $\bullet$ \\
\hline Russian Federation & 1985 & 0.51 & $\bullet$ & & $\bullet$ & $\bullet$ \\
\hline Rwanda & 1985 & & & & $\bullet$ & $\bullet$ \\
\hline Samoa & 1980 & 0.21 & $\bullet$ & & & \\
\hline Saudi Arabia & 1980 & 0.04 & $\bullet$ & & $\bullet$ & $\bullet$ \\
\hline Sierra Leone & 1985 & & & & $\bullet$ & $\bullet$ \\
\hline Slovak Republic & 1988 & 0.29 & $\bullet$ & $\bullet$ & $\bullet$ & $\bullet$ \\
\hline Slovenia & 1986 & 0.23 & $\bullet$ & $\bullet$ & $\bullet$ & $\bullet$ \\
\hline Solomon Islands & 1980 & 0.12 & $\bullet$ & $\bullet$ & $\bullet$ & $\bullet$ \\
\hline South Africa & 1980 & 0.11 & $\bullet$ & $\bullet$ & $\bullet$ & $\bullet$ \\
\hline Spain & 1980 & 0.14 & $\bullet$ & $\bullet$ & $\bullet$ & $\bullet$ \\
\hline Sri Lanka & 1980 & 0.17 & $\bullet$ & $\bullet$ & $\bullet$ & $\bullet$ \\
\hline Sudan & 1980 & 0.34 & $\bullet$ & $\bullet$ & $\bullet$ & $\bullet$ \\
\hline Swaziland & 1980 & 0.18 & $\bullet$ & $\bullet$ & & \\
\hline Sweden & 1980 & 0.12 & $\bullet$ & $\bullet$ & $\bullet$ & $\bullet$ \\
\hline Switzerland & 1980 & 0.17 & $\bullet$ & $\bullet$ & $\bullet$ & $\bullet$ \\
\hline Syrian Arab Republic & 1980 & 0.24 & $\bullet$ & $\bullet$ & $\bullet$ & $\bullet$ \\
\hline Tajikistan & 1985 & & & & $\bullet$ & $\bullet$ \\
\hline Tanzania & 1980 & 0.13 & $\bullet$ & $\bullet$ & $\bullet$ & $\bullet$ \\
\hline Thailand & 1980 & 0.31 & $\bullet$ & $\bullet$ & $\bullet$ & $\bullet$ \\
\hline Tonga & 1985 & & & & $\bullet$ & $\bullet$ \\
\hline Trinidad and Tobago & 1980 & 0.20 & $\bullet$ & $\bullet$ & $\bullet$ & $\bullet$ \\
\hline Tunisia & 1980 & 0.24 & $\bullet$ & $\bullet$ & $\bullet$ & $\bullet$ \\
\hline Turkey & 1980 & 0.30 & $\bullet$ & $\bullet$ & $\bullet$ & $\bullet$ \\
\hline Turkmenistan & 1988 & & & & $\bullet$ & \\
\hline Uganda & 1980 & 0.19 & $\bullet$ & $\bullet$ & $\bullet$ & $\bullet$ \\
\hline Ukraine & 1990 & & & & $\bullet$ & \\
\hline United Arab Emirates & 1985 & & & & $\bullet$ & $\bullet$ \\
\hline United Kingdom & 1980 & 0.20 & $\bullet$ & & $\bullet$ & $\bullet$ \\
\hline United States & 1980 & 0.08 & $\bullet$ & $\bullet$ & $\bullet$ & $\bullet$ \\
\hline Uruguay & 1980 & 0.37 & $\bullet$ & $\bullet$ & $\bullet$ & $\bullet$ \\
\hline Uzbekistan & 1990 & & & & $\bullet$ & \\
\hline Vanuatu & 1980 & 0.31 & $\bullet$ & $\bullet$ & & \\
\hline Venezuela & 1980 & 0.41 & $\bullet$ & & $\bullet$ & $\bullet$ \\
\hline Vietnam & 1985 & & & & $\bullet$ & $\bullet$ \\
\hline Yemen, Rep. & 1990 & & & & $\bullet$ & \\
\hline Zambia & 1980 & 0.31 & $\bullet$ & & $\bullet$ & $\bullet$ \\
\hline Zimbabwe & 1980 & 0.21 & $\bullet$ & & $\bullet$ & $\bullet$ \\
\hline Total number of countries & & & 118 & 103 & 128 & 121 \\
\hline
\end{tabular}

Pooling refers to column (4), while RCM (random coefficient model) refers to column (6) 


\section{References}

Acemoglu, D., Johnson, S., Querubin, P., \& Robinson, J. (2008). When does policy reform work? The case of central bank independence. NBER Working Paper 14033.

Arnone, M., Laurens, B., Segalotto, J., \& Sommer, M. (2007). Central bank autonomy: lessons from global trends. IMF Working Paper 07/88.

Bouwman, K., Jong-A-Pin, R. M., \& De Haan, J. (2005). On the relationship between central bank independence and inflation: some more bad news. Applied Financial Economics Letters, 1, 381-385.

Bryk, A., \& Raudenbusch, S. (1992). Hierarchical linear models: application and data analysis. Newbury Park: Sage.

Burney, N. A. (1995). Socio-economic development and electricity consumption: a crosscountry analysis using the random coefficient method. Energy Economics, 17, 185-195.

Burney, N. A. (1996). Exports and economic growth: evidence from cross-country analysis. Applied Economics Letters, 3, 369-373.

Campillo, M., \& Miron, J. A. (1997). Why does inflation differ across countries? In C. D. Romer \& D. H. Romer (Eds.), Reducing inflation: motivation and strategy (pp. 335-357). Chicago: University of Chicago Press.

Cukierman, A. (2008). Central bank independence and monetary policy-making institutions: past, present and future. European Journal of Political Economy, 24, 722-736.

Cukierman, A., Webb, S., \& Neyapti, B. (1992). Measuring the independence of central banks and its effects on policy outcomes. The World Bank Economic Review, 6, 353-398.

Databanks International (2005). Cross-national time-series data archive, 1815-2003. Binghamton, NY.

Dolmas, J., Huffman, G. W., \& Wynne, M. A. (2000). Inequality, inflation and central bank independence. Canadian Journal of Economics, 33, 271-287.

Dreher, A., Sturm, J.-E., \& De Haan, J. (2008). Does high inflation cause central bankers to lose their job? Evidence based on a new data set. European Journal of Political Economy, 24, 778-787.

Garofalo, G. G., \& Yamarik, S. (2002). Regional convergence: new evidence from a state-bystate capital stock series. Review of Economics and Statistics, 84, 316-323.

Grilli, V., Masciandaro, D., \& Tabellini, G. (1991). Political and monetary institutions and public finance policies in the industrial countries. Economic Policy, 6, 342-392.

Franzese, R. (1999). Partially independent central banks, politically responsive governments, and inflation. American Journal of Political Science, 43, 681-706.

Han, G., Kalirajan, K. P., \& Singh, N. (2002). Productivity and economic growth in East Asia: innovation, efficiency and accumulation. Japan and the World Economy, 14, 401-424.

Jácome, L., \& Vázquez, F. (2008). Is there any link between legal central bank independence and inflation? Evidence from Latin America and the Caribbean. European Journal of Political Economy, 24, 788-801.

Kilponen, J. (1999). Central bank independence and wage bargaining structure-empirical evidence. Bank of Finland Discussion Paper No. 9/99.

Kirchgässner, G. (1983). The political business cycle if the government is not myopic: an integration of the long-run and short-run models of the political business cycle. Mathematical Social Sciences, 4, 243260.

Kirchgässner, G. (1991). On the relation between voting intention and the perception of the general economic situation: an empirical analysis for the Federal Republic of Germany, 1972-1986. European Journal of Political Economy, 7, 497-526.

Klomp, J., \& De Haan, J. (2010). Inflation and central bank independence: a meta-regression analysis. Journal of Economic Surveys. doi:10.1111/j.1467-6419.2009.00597.x.

Koenker, R. (2005). Quantile regressions. Cambridge: Cambridge University Press.

Levy-Yeyati, E., \& Sturzenegger, F. (2005). Classifying exchange rate regimes: deeds vs. words. European Economic Review, 49, 1603-1635.

List, J. A., \& Gallet, C. A. (1999). The environmental Kuznets curve: does one size fit all? Ecological Economics, 31, 409-423.

Meade, E., \& Crowe, C. (2007). The evolution of central bank governance around the world. Journal of Economic Perspectives, 21, 69-90.

Pesaran, M. H., Shin, Y., \& Smith, R. (1999). Pooled mean group estimation of dynamic heterogeneous panels. Journal of the American Statistical Association, 94, 621-634.

Temple, J. (1998). Central bank independence and inflation: good news and bad news. Economics Letters, $61,215-219$.

Walsh, C. (2005). Central bank independence, prepared for the New Palgrave Dictionary, December 2005 (downloaded from: http://econ.ucsc.edu/ walshc/; last time assessed 13 December 2006). 